\title{
Peningkatan Kemampuan Menulis Karangan Dekripsi Dengan Menggunakan Media Gambar
}

\section{Aryani}

\begin{abstract}
Writing is a processof delivering ideas and messages, feelings and information to the readers through creative process and this activity needs knowledge and skill, so the readers can easily and clearly undertand the ideas or messages of the writer. One of writng texts is descriptive text which describes about something. There are some factors which make the writer can not deliver and write his or her ideas about describing something. This condition is caused by the media which is used by the teacher in the classroom is not interesting and cannot motivate the students to write descriptive text. This research is about increasing students'ability in writing descriptive text by using pictures By using pictures, the students can be motivated to write and to deliver their ideas to descrite something well.
\end{abstract}

Key words: Writing ability, descrptive text, picture

Copyright (C) 2016 IICET (Padang - Indonesia) - All Rights Reserved Indonesian Institute for Counseling, Education and Theraphy (IICET)

\section{PENDAHULUAN}

Dalam pembelajaran bahasa Indonesia terdapat empat aspek keterampilan bahasa yakni menyimak, berbicara, membaca, dan menulis. Walaupun menulis menduduki posisi paling akhir, tetapi menulis mempunyai banyak fungsi yang sangat penting bagi pengembangan intelektual seseorang, salah satunya yaitu untuk mengemukakan sesuatu. Melalui keterampilan menulis, peserta didik dapat mengeskpresikan pikiran, ide, serta gagasannya kepada orang lain.

Menurut Tarigan (1982:3), menulis adalah suatu keterampilan berbahasa yang dipergunakan untuk berkomunikasi secara tidak langsung, tidak secara tatap muka dengan orang lain. Komunikasi itu berlangsung dengan cara penulis mengungkapkan suatu ide maupun gagasannya melalui tulisan dan pembaca hanya dapat berinteraksi dengan penulis melalui tulisan itu. Sebagai salah satu bentuk komunikasi verbal menulis melibatkan unsur penulis sebagai penyampaian pesan atau isi tulisan, dan pembaca sebagai penerima pesan.

Selanjutnya Semi (2003:5) mengemukakan bahwa menulis merupakan suatu proses yang kreatif. Sebagai suatu proses yang kreatif, menulis harus mengalami suatu proses yang secara sadar dilalui dan dapat pula dilihat dengan hubungan satu dengan yang lain, sehingga berakhir pada suatu tujuan yang jelas. Pakar lain, Tarigan (dalam Abdurrahman dan Ratna, 2003:151) menyatakan bahwa "menulis merupakan suatu kegiatan yang menyusun atau mengorganisasikan buah pikiran, ide atau gagasan dengan menggunakan rangkaian kalimat yang logis dan terpadu dalam bahasa tulis".

Pengalaman peneliti sebagai Guru Bahasa Indonesia di SMK Negeri 1 Sawahlunto mengamati bahwa Pertama, peserta didik cenderung malas jika ditugaskan menulis. Kebiasaan ini timbul karena alasan susah menuangkan ide ke dalam tulisan. Kedua, dalam proses pembelajaran, khususnya pelajaran menulis karangan deskripsi, peserta didik selalu menghadapi kendala. Hal ini dibuktikan dengan kurangnya pengetahuan peserta didik dalam membedakan jenis karangan yang akan mereka tulis, seperti tulisan deskripsi, eksposisi, narasi, argumentasi, dan persuasi. Menurut penulis ini merupakan kesalahan yang cukup mengganggu, jika membedakan karangan saja peserta didik belum bisa, bagaimana mungkin peserta didik mampu menulisnya. Ketiga, kurang tepatnya strategi yang dipilih guru dalam pembelajaran menulis, khususnya menulis karangan deskripsi, sehingga mengakibatkan pembelajaran di kelas kurang menarik dan terkesan monoton. peserta didik hanya dibekali dengan teori-teori kebahasaan dan metode ceramah yang membuat peserta didik pasif. 
Tujuan penelitian ini adalah untuk meningkatkan kemampuan menulis karangan deskripsi peserta didik kelas X AK2 SMK N 1 Sawahlunto .Dalam hal ini penulis mengambil alternatif yaitu dengan menggunakan media gambar. Pemilihan media gambar ini dianggap mampu dan tepat untuk pelaksaanaan pembelajaran keterampilan menulis karangan deskripsi sebab melalui media gambar ini dapat memberikan rangsangan motivasi bagi peserta didikdan dianggap mudah dipahami peserta didik sehingga mereka akan lebih mudah mengungkapkan ide atau gagasannya terutama dalam menulis karangan deskripsi. Dengan demikian dapat diharapkan meningkatkan hasil belajar peserta didik.

\section{METODOLOGI PENELITIAN}

Metodologi penelitian ini adalah Penelitian Tindakan Kelas sebagai metode yang tepat untuk melaksanakan penelitian karena penelitian ini dilaksanakan oleh guru untuk memahami proses belajar mengajar yang dialaminya. Penelitian ini dilakukan di SMK Negeri 1 Sawahlunto pada kelas XAK2 Semester 2 Tahun Pelajaran 2015/2016 dengan jumlah peerta didik 27 orang terdiri dari 21 orang perempuan dan 6 orang laki-laki.

Menurut Arikunto (2006:16), ada empat langkah utama dalam penelitian tindakan yakni:

1. Perencanaan

Hal-hal yang dilakukan pada perencanaan ini adalah sebagai berikut:

a. Melakukan diskusi mengenai media yang akan diterapkan dalam menulis karangan deskripsi

b. Menyusun rencana tindakan berupa model Rencana Pelaksanaan Pembelajaran (RPP), yang meliputi halhal sebagai berikut: menetapkan standar kompetensi, memilih kompetensi dasar, menetapkan indikator, memilih materi, menetapkan kegiatan belajar mengajar, menetapkan media dan sumber belajar, dan evaluasi.

2. Pelaksanaan atau tindakan

Hal-hal yang dilakukan pada pelakanaan ini adalah sebagai berikut:

a. Menyiapkan peserta didik untuk mengikuti pembelajaran

b. Mengaitkan topik dengan pengetahuan peserta didik

c. Meningkatkan kemampuan menulis karangan deskripsi

d. Memantapkan penulisan dalam menulis karangan deskripsi berdasarkan gambar yang diamati

3. Pengamatan

Hal-hal yang dilakukan pada pelakanaan ini adalah sebagai berikut:

a. Pengamatan pada proses pemberian tindakan oleh guru

b. Observasi terhadap peran peserta didik dalam pembelajaran

c. Pada waktu pengamatan guru memberikan bimbingan individual kepada peserta didik yang belum mengerti baik materi pembelajaran maupun tugas.

4. Refleksi

Hal-hal yang dilakukan pada pelakanaan ini adalah sebagai beriku

a. Mengidentifikasi masalah yang tersisa pada siklus I

b. Memperhatikan kaitan antara satu masalah dengan lainnya

c. Mengkaji kembali mengapa masalah itu terjadi

d. Menyusun tindakan baru sebagai revisi dari tindakan yang telah dilakukan

\section{HASIL DAN PEMBAHASAN PENELITIAN}

\section{Siklus 1}

a. Tahap Perencanaan

Beberapa kegiatan yang dilakukan sebagai persiapan untuk pelaksanaan penelitian adalah: 1) mempersiapkan Rencana Pelaksanaan Pembelajaran, 2) menyiapkan alat dan media yang dibutuhkan, 3) menyiapkan instrumen penelitian, seperti lembar observasi untuk memantau aktivitas peserta didik dan guru dalam pelaksanaan pembelajaran,angket respons peserta didik, angket wawancara yang digunakan untuk memperkuat data observasi yang terjadi di kelas, baik dari unsur guru maupun peserta didik, 4) menghubungi pihak-pihak yang dibutuhkan untuk terlaksananya penelitian tindakan kelas seperti kepala sekolah dan guru kolaborator,5) menetapkan waktu pelaksanan, 6) menetapkan media gambar untuk tes menulis karangan deskripsi. 


\section{b. Tahap Tindakan}

Tahap tindakan ini merupakan wujud nyata dari persiapan-persiapan yang telah dilakukan pada tahap perencanaan sebelumnya.pelaksanaan pembelajaran ini diuraikan berdasarkan langkah-langkah sebagai berikut:

Pertemuan I

Guru memberi penjelasan Materi Tentang Karangan Deskripsi dan Cara Menulis Karangan Deskripsi Menggunakan Media Gambar. Guru membacakan sebuah contoh karangan deskripsi dan menyuruh siswa memikirkan dan memahami ciri-ciri apa saja yang terdapat dalam karangan deskripsi yang dibacakan.Selanjutnya, guru mulai menjelaskan tujuan pembelajaran menulis karangan deskripsi menggunakan media gambar sesuai dengan ciri-ciri karangan deskripsi, yaitu 1) memperlihatkan rincian tentang objek, 2) memberikan pengaruh sensitivitas, 3) menggunakan pilihan kata yang tepat, 4) memaparkan tentang sesuatu yang dapat didengar, dilihat, dan dirasakan, 5) menggunakan susunan ruang. Kegiatan selanjutnya adalah kegiatan inti.yakni memberikan penjelasan cara menulis karangan deskripsi menggunakan media gambar. Berikutnya adalah memberikan kesempatan bertanya kepada peserta didik tentang materi yang telah dijelaskan.Pada kegiatan akhir, guru meminta beberapa orang peserta didik untuk menyimpulkan materi pelajaran yang telah dijelaskan dan menutup pelajaran.

\section{Pertemuan 2}

Fokus pembelajaran pada pertemuan kedua siklus 1 ini adalah menulis karangan deskripsi menggunakan media gambar.Diawali dengan apersepsi kemudian guru mengadakan tanya jawab dengan peserta didik tentang pelajaran yang lalu mengenai pengertian deskripsi, jenis-jenis deskripsi, ciri-ciri deskripsi, dan cara menulis karangan deskripsi menggunakan media gambar. Kemudian guru memberikan kesempatan kepada peserta didik untuk bertanya tentang materi yang telah dijelaskan dan menanyakan kendala apa saja yang ditemukan dalam menulis karangan deskripsi.Guru menjelaskan tujuan pembelajaran yang dilaksanakan, yakni agar peserta didik mampu mendata objek yang akan dijadikan bahan dalam menulis karangan deskripsi berdasarkan ciri-ciri karangan deskripsi yang telah dijelaskan. Pada kegiatan inti ini, guru membacakan sebuah contoh karangan deskripsi yang berbeda dengan pertemuan pertama kemudian membahas karangan deskripsi tersebut berdasarkan ciri-ciri karangan deskripsi yang telah dijelaskan pada pertemuan sebelumnya.Contoh karangan deskripsi pada pertemuan kedua siklus 1 ini dikutip dari "Siti Nurbaya", Marah Rusli dalam Gani (1999:150). Guru memajang sebuah gambar pemandangan di papan tulis. guru meminta peserta didik untuk duduk berkelompok menurut urutan tempat duduknya masing-masing. Masing-masing anggota kelompok terdiri atas empat orang.Setelah itu, guru membagikan gambar pemandangan pantai sesuai dengan gambar yang sudah dipajang di papan tulis kepada masing-masing kelompok dan meminta peserta didik mendiskusikan seluk-beluk objek pemandangan yang diamati.Setelah bertanya jawab mengenai kemudahan-kemudahan dan kesulitan menulis karangan deskripsi dengan media gambar diketahui bahwa peserta didik lebih mudah berimajinasi dan menemukan ide dalam menulis karangan deskripsi dengan menggunakan media gambar, peserta didik lebih bisa memaparkan ciri-ciri karangan deskripsi. Kesulitan-kesulitan yang ditemukan peserta didik adalah dalam memahami cara menulis karangan deskripsi dengan media gambar karena penyampaian materi oleh guru terlalu cepatdanwaktu yang diberikan guru sangat singkat. Ppeserta didik juga masih sulit untuk memahami materi tentang ciri-ciri deskripsi terutama pemilihan diksi dan memberikan pengaruh sensitivitas serta imajinasi pembaca. Pada kegiatan akhir, guru dan peserta didik kembali mengukuhkan pelajaran dan menyimpulkan pelajaran yang sudah berlangsung.

\section{Pertemuan 3}

Fokus penelitian pada pertemuan ketiga siklus1 ini adalah membahas hasil tes menulis karangan deskripsi menggunakan media gambar yang telah dilaksanakn pada pertemuan sebelumnya dan peserta didikmengisi angket responterhadap pembelajaran menulis karangan deskripsi menggunakan media gambar.

\section{c.Tahap Observasi/Evaluasi}

Yang diamati adalah peristiwa yang menjadi indikator keberhasilan atau ketidakberhasilan pemecahan masalah dan pengembangan teknik pembelajaran yang sedang dilaksanakan. Observasi ini dilakukan dengan dua cara yaitu menganalisis hasil kerja peserta didik dan lembar observasi serta angket respons peserta didik terhadap pembelajaran. Berdasarkan tabel rambu rambu keberhasilan tindakan guru pertemuan 1, 2 dan 3 dapat disimpulkan bahwa mulai dari kegiatan awal hingga kegiatan akhir yang dilaksanakan guru semuanya terlaksana dengan baik. 
Berdasarkan hasil tes siklus 1, didapatkan kesimpulan bahwa skor rata rata yang diperoleh peserta didik dalam menulis karangan deskripsi belum mencapai Kriteria Ketuntasan Minimal (KKM) yang ditetapkan yaitu, 7,50. Hasil pengamatan skor, nilai dan klasifikasi nilai per indikator dapat dilihat pada tabel 1:

Tabel 1

Persentase Perolehan Skor Rata-rata Per Indikator Siklus 1

\begin{tabular}{lllll}
$\mathbf{N}$ & \multicolumn{1}{c}{ Indikator } & \multicolumn{1}{c}{ Persentase } & \multicolumn{1}{c}{ Klasifikasi Nilai } & \multicolumn{1}{c}{ Keterangan } \\
\hline $\mathbf{1}$ & $\begin{array}{l}\text { Detail atau Perincian tentang } \\
\text { Objek }\end{array}$ & $83,7 \%$ & Baik & Tuntas \\
$\mathbf{2}$ & $\begin{array}{l}\text { MemberiPengaruh } \\
\text { Sensitivitas dan Imajinasi }\end{array}$ & $66,7 \%$ & Lebih Dari Cukup & Tidak Tuntas \\
$\mathbf{3}$ & $\begin{array}{l}\text { Pemilihan Diksi yang } \\
\text { Menggugah dan Memikat }\end{array}$ & $53,3 \%$ & Hampir Cukup & Tidak Tuntas \\
$\mathbf{4}$ & $\begin{array}{l}\text { Memaparkan Sesuatu yang } \\
\text { Dapat Didengar, Dilihat, dan } \\
\text { Dirasakan }\end{array}$ & $59,3 \%$ & Cukup & Tidak Tuntas \\
$\mathbf{5}$ & $\begin{array}{l}\text { Menggunakan susunan } \\
\text { ruang }\end{array}$ & $64,4 \%$ & Cukup & Tidak Tuntas \\
\hline
\end{tabular}

Sedangkan hasil angket respon peserta didik dapat dilihat pada tabel 2, yaitu:

Tabel 2

Hasil Angket Respon Peserta Didik Siklus 1

\begin{tabular}{|c|c|c|c|c|c|c|}
\hline No & Pernyataan & $\begin{array}{c}\text { Sangat } \\
\text { suka }\end{array}$ & Suka & $\begin{array}{c}\text { Kurang } \\
\text { Suka }\end{array}$ & $\begin{array}{l}\text { Tidak } \\
\text { Suka }\end{array}$ & $\begin{array}{c}\text { Sangat } \\
\text { Tidak } \\
\text { suka }\end{array}$ \\
\hline 1 & $\begin{array}{l}\text { Keterampilan menulis karangan deskripsi } \\
\text { dapat meningkatkan kreativitas saya } \\
\text { dalam belajar. }\end{array}$ & $44,4 \%$ & $29,6 \%$ & $14,8 \%$ & $11,1 \%$ & - \\
\hline 2 & $\begin{array}{l}\text { Media gambar yang digunakan oleh guru } \\
\text { dapat memotivasi saya untuk menulis } \\
\text { karangan deskripsi. }\end{array}$ & $55,6 \%$ & $33,3 \%$ & $7,4 \%$ & $3,7 \%$ & - \\
\hline 3 & $\begin{array}{l}\text { Saya merasa senang terhadap cara guru } \\
\text { menerangkan keterampilan menulis } \\
\text { karangan deskripsi menggunakan media } \\
\text { gambar. }\end{array}$ & $44,4 \%$ & $37,04 \%$ & $18,5 \%$ & - & - \\
\hline 4 & $\begin{array}{l}\text { Media gambar dapat memudahkan saya } \\
\text { menemukan ide sehingga saya dapat } \\
\text { menulis karangan deskripsi dengan baik. }\end{array}$ & $44,4 \%$ & $33,3 \%$ & $18,5 \%$ & $3,7 \%$ & - \\
\hline 5 & $\begin{array}{l}\text { Pembelajaran yang dilakukan oleh guru } \\
\text { sekarang lebih menyenangkan. }\end{array}$ & $55,6 \%$ & $33,3 \%$ & $11,1 \%$ & - & - \\
\hline 6 & $\begin{array}{l}\text { Materi yang diberikan guru relevan } \\
\text { dengan tujuan pembelajaran. }\end{array}$ & $59,3 \%$ & $37,04 \%$ & $3,7 \%$ & - & - \\
\hline 7 & $\begin{array}{l}\text { Saya senang dengan pembelajaran } \\
\text { menulis karangan deskripsi dengan media } \\
\text { gambar. }\end{array}$ & $55,6 \%$ & $29,6 \%$ & $11,1 \%$ & $3,7 \%$ & - \\
\hline 8 & $\begin{array}{l}\text { Mempelajari pelajaran menulis karangan } \\
\text { deskripsi dengan media gambar lebih } \\
\text { meningkatkan pemahaman saya dibanding } \\
\text { dengan metode ceramah. }\end{array}$ & $59,3 \%$ & $22,2 \%$ & $18,5 \%$ & - & - \\
\hline 9 & $\begin{array}{l}\text { Latihan yang diberikan guru dapat } \\
\text { memantapkan pemahaman saya tentang } \\
\text { menulis karangan deskripsi. }\end{array}$ & $55,6 \%$ & $29,6 \%$ & $11,1 \%$ & $3,7 \%$ & - \\
\hline 10 & $\begin{array}{l}\text { Menurut saya penggunaan media gambar } \\
\text { dalam menulis karangan deskripsi relevan }\end{array}$ & $66,7 \%$ & $25,9 \%$ & $7,4 \%$ & - & - \\
\hline
\end{tabular}


dengan tujuan pembelajaran bahasa

Indonesia.

\begin{tabular}{|c|l|l|l|l|c|}
\hline Jumlah & 550,9 & 310,9 & 122,1 & 25,9 & 0 \\
\hline Rata-Rata & $55,1 \%$ & $31,1 \%$ & $12,2 \%$ & $2,6 \%$ & $0 \%$ \\
\hline
\end{tabular}

Dari tabel 1 dan 2 terlihat bahwa:

1.Rata-rata nilai kemampuan menulis karangan deskripsi peserta didik menggunakan media gambar secara keseluruhan pada siklus I adalah $64 \%$.

2. Rata-rata hasil angket respons peserta didik pada siklus I terhadap pembelajaran adalah $55,1 \%$ berada pada klasifikasi sangat suka, 31,1\% suka, 12,2\% kurang suka dan 2,6\% tidak suka.

Tindakan siklus I dinyatakan belum berhasil karena belum mencapai Kriteria Ketuntasan Minimal (KKM) 75\%sehingga perlu dilaksanakan siklus II.

\section{d.Tahap Refleksi}

Ditemukan enam masalah dalam pelaksanaan kegiatan pada siklus 1, yaitu: 1) kekurangan waktu, 2) penguasaan kelas yang kurang baik, 3) guru masih mendominasi perannya dari seluruh tahapan pembelajaran, 4) kurangnya pemahaman peserta didik tentang ciri-ciri deskripsi terutama dalam memberikan pengaruh sensitivitas dan menggunakan diksi (pilihan kata) yang menggugah, 5) penyampaian guru yang terlalu cepat sehingga siswa kurang memahami penjelasan yang disampaikan.Dari hasil refleksi tersebut, perlu diadakan pelaksanaan siklus II guna mewujudkan sebuah peningkatan belajar. Untuk pelaksanaan siklus II, tentu kelemahan-kelamahan pada siklus 1 harus disiasati.

\section{Siklus 2}

a. Tahap Perencanaan

Pelaksanaan penelitian tindakan siklus II dilaksanakan dengan tiga kali pertemuan. Pertemuan pertama dilaksanakan pada hari Kamis, tanggal 3 Maret 2016, pertemuan kedua dilaksanakan pada hari Kamis, tanggal 10 Maret 2016, dan pertemuan ketiga dilaksanakan pada hari Kamis, tanggal 17 Maret 2016. kegiatan yang dilakukan pada perencanaan siklus II ini adalah sebagai berikut: 1) membuat rencana pelaksanaan pembelajaran sesuai dengan kompetensi dasar yang dipilih, 2) menyiapkan alat dan media yang dibutuhkan, 3) menyiapkan instrumen penelitian yaitu berupalembar observasi, angket respons peserta didik dan wawancara yang digunakan untuk memperkuat data observasi, 3) menetapkan waktu pelaksanaan.

\section{b. Tahap Tindakan \\ Pertemuan I}

Kegiatan difokuskan pada memantapkan materi tentang deskripsi dan cara menulis karangan deskripsi menggunakan media gambar dengan kegiatan pendahuluan sebagai berikut: 1)guru masuk dengan mengucapkan salam, lalu mengecek kehadiran peserta didik, 2)guru melakukan kegiatan apersepsi dengan bertanya jawab tentang materi menulis karangan deskripsi dan menulis karangan deskripsi menggunakan media gambar, 3)guru menampilkan sebuah contoh karangan deskripsi yang berbeda dengan contoh karangan deskripsi yang ditampilkan pada penjelasan materi siklus I dan menyuruh peserta didik untuk memperhatikan contoh karangan deskripsi yang dibacakan, 4)guru menyampaikan tujuan pembelajaran.

Kegiatan ini, yaiyu: 1)guru memantapkan materi sesuai dengan indikator yang dinilai, 2)guru memberikan kesempatan kepada peserta didik untuk bertanya apabila masih ada diantara mereka yang masih belum memahami materi yang telah diterangkan, 3)guru bersama peserta didik membahas karangan deskripsi yang ditulis pada siklus 1sebagai contoh tambahan menguatkan pemahaman peserta didik dalam menulis karangan deskripsi menggunakan media gambar.

Kegiatan terakhir adalah kegiatan penutup.Pada kegiatan akhir ini setelah memberikan penjelasan materi tersebut guru meminta peserta didik menyimpulkan pelajaran dan guru menutup pelajaran.

\section{Pertemuan 2}

Pada pertemuan kedua ini kegiatan inti yang dilakukan guru adalah kegiatan menulis karangan deskripsi menggunakan media gambar.Gambar yang diberikan pada pertemuan kedua siklus II ini berbeda dengan gambar yang diberikan pada siklus 1 tetapi objek dari masing-masing gambar tersebut sama.

Pertemuan 3

Pembelajaran pada pertemuan ketiga difokuskan pada kegiatan membahas karangan deskripsi menggunakan media gambar yang telah ditulis pada pertemuan sebelumnya dan mengisi angket respons 
peserta didik.Guru merangkum/ menyimpulkan pelajaran hari ini kemudian guru menilai hasil kerja peserta didik.

\section{c.Tahap Observasi/Evaluasi}

Dapat disimpulkan secara keseluruhan kegiatan guru dalam setiap pertemuan baik pada pertemuan pertama, kedua, dan ketiga pada siklus II semuanya terlaksana dengan baik. Semua kegiatan yang seharusnya dilakukan guru semuanya telah dilaksanakan guru dengan baik dan terarah. Kesempurnaan kegiatan guru tersebut berdasarkan beberapa perbaikan yang dilakukan untuk siklus II serta perencanaan yang baik oleh guru untuk siklus II berdasarkan pengalaman yang telah didapat pada siklus sebelumnya.Untuk melihat keberhasilan penerapan siklus II baik pada pertemuan pertama, kedua, dan ketiga pada kegiatan peserta didik digunakan tes unjuk kerja siswa, lembar observasi kegiatan pembelajaran, angket respon didik terhadap pembelajaran, dan format wawancara terhadap pembelajaran yang sudah dilaksanakan.Berdasarkan hasil tes siklus 2, didapatkan kesimpulan bahwa skor rata rata yang diperoleh peserta didik dalam menulis karangan deskripsi telah mencapai Kriteria Ketuntasan Minimal (KKM) yang ditetapkan yaitu, 7,50. Hasil pengamatan skor, nilai dan klasifikasi nilai per indikator dapat dilihat pada tabel 3:

\section{Tabel 3}

Persentase Perolehan Skor Rata-rata Per Indikator Siklus 2

\begin{tabular}{|c|c|c|c|c|}
\hline No & Indikator & Persentase & Klasifikasi Nilai & Keterangan \\
\hline 1 & $\begin{array}{l}\text { Detail atau Perincian tentang } \\
\text { Objek }\end{array}$ & $98,5 \%$ & Sempurna & Tuntas \\
\hline 2 & $\begin{array}{l}\text { MemberiPengaruh } \\
\text { Sensitivitas dan Imajinasi }\end{array}$ & $98,5 \%$ & Sempurna & Tuntas \\
\hline 3 & $\begin{array}{l}\text { Pemilihan Diksi yang } \\
\text { Menggugah dan Memikat }\end{array}$ & $80 \%$ & Baik & Tuntas \\
\hline 4 & $\begin{array}{l}\text { Memaparkan Sesuatu yang } \\
\text { Dapat Didengar, Dilihat, dan } \\
\text { Dirasakan }\end{array}$ & $80,7 \%$ & Baik & Tuntas \\
\hline \multirow[t]{2}{*}{5} & $\begin{array}{l}\text { Menggunakan susunan } \\
\text { ruang }\end{array}$ & $85,9 \%$ & Baik & Tuntas \\
\hline & Total Rata-rata Kelas & $86,5 \%$ & Baik sekali & Tuntas \\
\hline
\end{tabular}

Dari tabel 3 terlihat bahwa: kemampuan menulis karangan deskripsi secara umum mengalami peningkatan jika dibandingkan dengan hasil siklus I,dan telah mencapai Kriteria Ketuntasan Minimal (KKM) 75\%. Dan dari hasil analisis angket respons peserta didik secara keseluruhan rata-rata hasil angket respons peserta didik pada siklus II terhadap pembelajaran adalah $\mathbf{8 6 , 5 \%}$ berada pada klasifikasi sangat baik.

\section{d.Tahap Refleksi}

Latihan-latihan yang telah diberikan oleh guru dalam menulis karangan deskripsi, penanganan pada hambatan yang ditemukan, dan kesulitan dalam pembelajaran telah membuat peserta didik menjadi senang dan tertarik hingga peserta didik mampu menulis karangan deskripsi dengan baik. Hal ini dapat ditingkatkan lagi dengan cara memberikan latihan yang lebih banyak bagi peserta didik. Selain itu, tingkat penguasaan kemampuan menulis karangan deskripsi peserta didik telah mencapai Kriteria Ketuntasan Minimal (75\%). Hal ini berarti, pelaksanaan penelitian tindakan kelas dengan menggunakan media gambar dan penerapan pola diskusi/ tanya jawab serta kerja sama kelompok, telah berhasil membawa perubahan hasil belajar peserta didik dengan II siklus pembelajaran. Dengan timbulnya antusias dan semangat belajar yang membaik, maka kegiatan pembelajaran tidak lagi terpusat pada guru. Peserta didik berperan aktif dalam setiap kegiatan yang melibatkan keikutsertaan mereka.

Berdasarkan deskripsi hasil penelitian tes awal, siklus I dan siklus II, dapat disajikan tabulasi kemampuan rata-rata menulis karangan deskripsi menggunakan media gambar peserta didik kelas X AK2 SMK N 1 Sawahlunto per indikator maupun dari sebelum pelaksanaan siklus 1 hingga akhir siklus II. Terdapat peningkatan yang signifikan terhadap kemampuan menulis karangan deskripsi peserta didik kelas $\mathrm{X}$ AK2 SMK N 1 Sawahlunto menggunakan media gambar. 


\section{PEMBAHASAN}

Hasil penelitian menunjukkan bahwa penggunaan media gambar secara signifikan meningkatkan kemampuan menulis karangan deskripsi peserta didik, baik dalam memberikan perincian objek, memberikan pengaruh sensitivitas, menggunakan pilihan kata yang menggugah, memaparkan sesuatu yang dapat didengar, dilihat, dan dirasakan, dan menggunakan susunan ruang. Dari hasil penelitian dan pantauan tersebut serta hasil evaluasi peserta didik dalam menulis karangan deskripsi menggunakan media gambar dapat dilihat hasil perkembangan peserta didik dalam setiap evaluasi seperti yang tercantum dalam tabel berikut:

\begin{tabular}{|c|c|c|}
\hline & $\begin{array}{c}\text { Nilai } \\
\text { Rata Rata }\end{array}$ & $\begin{array}{c}\text { Kualifikasi } \\
\text { Skala } 10\end{array}$ \\
\hline Pra Siklus & 47,96 & Hampir Cukup \\
\hline Siklus I & 65,5 & Cukup \\
\hline Siklus II & 86,5 & Baik Sekali \\
\hline
\end{tabular}

Dari tabel tersebut dapat dilihat hasil tindakan pada setiap siklus. Dari pra siklus sampai siklus II kegiatan menulis karangan deskripsi dengan menggunakan media gambar mengalami peningkatan. Peserta didik dapat menulis dengan baik sehingga nilai rata rata untuk semua indikator mengalami peningkatan dri 47,96 menjadi 65,5 dan pada siklus II menjadi 86,5 dan menunjukkan hasil yang baik sekali. Namun peneliti berkeinginan untuk meningkatakan dengan menyempurnakan kekurangan, karena masih ada beberapa peserta didik yang belum tuntas.

Dari data respon peserta didik menunjukkan juga bahwa kegiatan menulis karangan desskripsi menggunakan media gambar juga disukai oleh peserta didik dan meereka termotivasi dengan baik dalam mengerjakan tugas.

Dalam melakukan penelitian ini guru menemui kendala seperti pada siklus I yaitu kurangnya waktu yang tersedia dan peserta didik belum terbiasa dan paham dengan menulis karangan deskripsi. Penjelasan guru juga belum dapat dipahami peserta didik dengan baik dan guru masih menemui kesulitan dalam penngelolaan kelas.

Hasil observasi dan refleksi guru menjadi acuan untuk meningkatkan nilai peserta didik. Gurupun menyusun rencana pembelajaran yang lebih baik pada siklus ke II. Waktu dan tenaga dipersiapkan lebih banyak. Dan pemilihan gambar sebagai mediapun ditentukan sesuai dengan minat dan keinginan peserta didik. Dari keseluruhan siklus yang telah dilakukan dapat disimpulkan bahwa guru telah melaksanakan kegiatan pembelajaran menulis karangan deskripsi menggunakan media gambar pada peserta didik kelas $\mathrm{X}$ AK2 SMK N 1 Sawahlunto.

\section{KESIMPULAN DAN SARAN}

Berdasarkan hasil penelitian, pengolahan data, dan pembahasan dapat disimpulkan, yaitu Pembelajaran menulis karangan deskripsi sudah dilaksanakan dengan beberapa teknik pengajaran di SMK Negeri 1 Sawahlunto di antaranya dengan teknik lamunan dan teknik melihat alam secara langsung atau yang dikenal dengan teknik objek langsung. Namun hasil yang diperoleh dari dua teknik ini masih belum memuaskan. Hal ini disebabkan karena terlalu luasnya objek yang akan dijadikan sumber inspirasi bagi peserta didik sehingga peserta didik sulit untuk menggunakan diksi, majas, dan citraan. Sehingga peserta didikmenulis karangan deskripsi dengan diksi, majas, dan citraan yang kurang baik. Media gambar diharapkan dapat meningkatkan kemampuan menulis karangan deskripsi peserta didik.

Proses peningkatan kemampuan menulis karangan deskripsi dengan menggunakan media gambar dilaksanakan dalam tiga tahap pada setiap siklusnya, yakni tahap menulis karangan deskripsi tanpa menggunakan media sebagai tes awal, tahap membahas karangan deskripsi tes awal dan penjelasan materi karangan deskripsi, dan tahap menulis karangan deskripsi dengan menggunakan media gambar serta mengisi angket respons peserta didik pada siklus I. pada siklus II tahap pembelajaran yang dilakukan adalah: pengukuhan materi pembelajaran tentang menulis karangan deskripsi, menulis karangan deskripsi dengan menggunakan media gambar, dan tahap membahas karangan deskripsi yang telah ditulis pada pertemuan sebelumnya serta mengisi angket respon peserta didik terhadap pembelajaran. 
Berdasarkan simpulan tersebut, maka peneliti menyarankan kepada guru Bahasa dan Sastra Indonesia untuk menciptakan pembelajaran yang menyenangkan. Salah satu caranya adalah dengan memilih teknik pembelajaran yang sesuai serta dilengkapi dengan media yang menarik yaitu dengan menggunakan media gambar. Sebelum peserta didik belajar membaca pemahaman, sebaiknya diberikan contoh dan latihan membaca pemahaman yang dapat dipahami peserta didik. Guru perlu persiapan yang matang dalam melaksanakan pembelajaran, sehingga peserta didik tidak merasa terbebani dalam menulis karangan deskripsi. Dengan demikian, siswa merasa nyaman sehingga terciptalah suasana yang kondusif dan tujuan pembelajaran pun tercapai dengan baik.

\section{DAFTAR PUSTAKA}

Abdurahman dan Ellya Ratna. 2003. "Evaluasi Pembelajaran Bahasa dan Sastra Indonesia" (Bahan Ajar). Padang: FBSS Padang.

Arikunto, Suharsimi, dkk. 2006. Penelitian Tindakan Kelas. Jakarta: Bumi Aksara.

Arsyad. A. 1997. Media Pembelajaran. Jakarta: PT Raja Grafindo Persada.

Atmazaki. 2006. Kiat-kiat Mengarang dan Menyunting. Padang: Yayasan Citra Budaya Indonesia.

Depdiknas. 2006. Standar Isi Kurikulum Tingkat Satuan Pendidikan SMA/MA. Jakarta: Depdiknas.

Gani, Erizal. 1999. "Pembinaan Keterampilan Menulis di Perguruan Tinggi” (Buku Ajar) Padang: DIP Proyek UNP.

Keraf, Gorys. 1982. Eksposisi dan Deskripsi. Ende: Nusa Indah.

Moleong. 2005. Metodologi Penelitian Kualitatif. Bandung: PT Remaja Rosdakarya.

Nazir, Mohammad. 1988. Metode Penelitian. Jakarta: Ghalia Indonesia.

Sadiman, Arief. S, dkk. 1990. Media Pendidikan. Jakarta: Rajawali.

Semi, M. Atar. 2003. Menulis Efektif. Padang: Angkasa Raya.

Sri Dewi, R. Nina. 2006. "Kemampuan Menulis Karangan Deskripsi dengan Menggunakan Media Gambar Oleh Siswa Kelas VII SMP Negeri 4 Padang Panjang”. Skripsi. Padang: Jurusan Bahasa dan Sastra Indonesia FBSS UNP.

Subana. M, dkk. 2003. Strategi Belajar Mengajar Bahasa Indonesia. Bandung: Pustaka Setia Bandung

Suleiman, Amir Hamzah. 1999. Media Audio-Visual. Jakarta: Gramedia.

Tarigan, Henry Guntur. 1983. Menulis Sebagai Suatu Keterampilan Berbahasa. Bandung: Angkasa.

Wardhani.IGAK, dkk. 2007. Penelitian Tindakan Kelas. Jakarta: Universitas Terbuka 